\title{
What is Visible and What Is Hidden. Cultural Landscape of Kizhinga Town: Between Local Native Traditions and State Ideology ${ }^{1}$
}

\section{Abstract}

The author refers to the elements of cultural landscape (natural and architectural objects) of Russian town, Kizhinga. The most important questions he tries to answer are: how can places, objects and spaces coming from different symbolic orders create a coherent cultural space and how have the meanings and connotations of local spatial forms changed? What is the result of the clash between local native traditions and state ideology, 20th century Soviet style modernization, and attempts to recreate traditions and ethno-cultural identity in a small-town space at the turn of the $21^{\text {st }}$ century.

Keywords: cultural landscape, Kizhinga, Buryatia, USSR, Russian Federation, symbolic order, tradition, ideology, culture, identity

By considering the contemporary cultural landscape of Kizhinga and the Kizhinga region, I will, at least partially, try to answer the following questions: what is the result of the clash of local pre-revolution traditions with state ideology, $20^{\text {th }}$ century Soviet style modernization, and attempts to recreate traditions and ethno-cultural identity in a small-town space at the turn of the $21^{\text {st }}$ century? How places, objects, spaces coming from different symbolic orders can create a coher-

1 The article is one of the effects of the original research project "Local contexts of social and cultural identity and the biographical experience of the inhabitants of Eastern Siberia". The field of research and theoretical significance regard the basic problems of sociology and anthropology of local communities, biography, cultural identity, civilizational and cultural borderland. 
ent cultural space and how the meanings and connotations of local spatial forms have changed? In this article I will refer both to the elements of natural landscape and architectural objects. ${ }^{2}$

Following Dobiesław Jędrzejczyk, I will consider the cultural landscape in terms of text, icons, spectacles or the way of observing the space we are interested in. A human being due to the requirements of his own existence must somehow understand it, i.e. read the meanings in various available languages. From the semiological point of view, therefore, landscape should be treated as a system of signs, and thus a phenomenon of communication. This means that individual messages of the human-landscape relation are organized and understandable in relation to codes, i.e. systems of signs enabling the transmission of information (Jędrzejczyk 2004: 210-211).

From this perspective, we assume that the physical space of human existence is covered by a cultural layer composed of symbols, signs, meanings, and emotions related to them, forming both social and individual ideas. A cultural landscape is thus composed of ideas about a given territory. These ideas can be defined as spatial images, images, myths, local and beyond local texts, judgments, valorization, ideological narratives (e.g. state or religious) absorbed both spontaneously and imposed top-down. Thus, a landscape understood in this way arises as a result of the coexistence, interpenetration, mutual influence, and even clash and conflict of various cultural contents, traditions, religions, ideologies, norms, values, and deep psychological structures.

Let's start with the general characteristics in the area of interest. The Kizhinga region (rus. Kizhinginskiy rayon; bur. Khezhengyn aimag ${ }^{3}$ ) is located in the territory of the Russian Federal Republic of Buryatia, which is part of the Far Eastern Federal District (before 2018, part of the East Siberian Federal District). The total number of inhabitants in the region is currently 18,200. In the area of 787 square kilometres, there are 9 somons (village councils) and 21 smaller hamlets. The centre of the region is the already mentioned town (rus. rayonny tsentr) of Kizhinga with 6373 inhabitants (2010). The official date of the creation of the area is December $12^{\text {th }}, 1940$, when a decision was made to divide Khorinski region (Khoriin aimag) into three smaller regions (Khorinski, Yeravninski and Kizhinginski). At that time, the area was mainly inhabited by representatives of the Khori-Buryat tribal group, one of the main compounds of the modern Buryat nation.

Next to the Buryats, the most numerous ethnic group in the Kizhinga region are ethnic Russians, who began to settle in these areas on a larger scale only in the $20^{\text {th }}$ century. The Russians are a diverse group here. Some of them are descendants of the so-called Semeyskie (Old Believers). In Eastern Siberia, the Semeyskie cre-

2 To put it briefly, I consider place as a part of material space that is saturated with meanings attributed by humans; it can also be associated with specific emotions, attachment, sensual associations, etc.

3 Aimag is a traditional Mongolian territorial division/unit. 
ated a specific cultural ethno-social formation with peculiar tradition, a sense of community, origin and distinctiveness. There are a few villages inhabited by this group in the region: Leonovka, Novokizhinginsk/Voznesenovka and Mikhailovka. Large ethnic groups of Russians also live in Kizhinga and Ushkhaita.

There are currently 3 Buddhist monasteries in the Kizhynga region. The leading monastery is Kizhinga Datsan, rebuilt in 1991, belonging to the Buddhist Traditional Sangha of Russia (the other two are smaller monasteries/temples, where the lamas appear during periodic retreats or cyclical holidays). In the last two decades, 13 free-standing suburgaans (stupas) have been built in the area. Some of them are devoted to figures important in the history of the region - lama Lubsan Samdan Tsydenov and Agvan Silnam, leaders of the theocratic quasi-republic established here briefly during the civil war of 1918-1921, the local tantrist Bidiya Dandaron and Vasily Repka, a Russian student of Dandaron. There are also suburgaans devoted to the repressed lamas, which were erected with funds collected by their families and neighbours, on the territory of the Kizhinga monastery.

There are also 6 Orthodox churches in the area, which were only built in the first few years of the $21^{\text {st }}$ century (the most important of them are: the SvyatoVladimirskaya church in Kizhinga, Svyato-Voznesenskaya in Ushkhaita and Lubov Khrista in Novokizhinginsk/Voznesenowka). There are also 12 cult places of oboo ${ }^{4}$ and sacred mountains in the Kizhinga region. One of the most important is Mount Chelsana, the symbolic and sacred centre of the Kizhinga Valley.

When looking at the symbolic space of the region, it is worth paying attention to 40 archaeological sites. The oldest are from the Neolithic period. These are the remains of human settlements, plate tombs from the $2^{\text {nd }}-3^{\text {rd }}$ millennium (bronze age), rock drawings, etc. Many of these places have grown up with local legends and stories. Some have become unofficial places of worship.

In addition to strictly sacred objects in the area, there are also places associated with propaganda and secular state rituals. They include 25 monuments which create a symbolic space of memory. Most of them refer to the Great Patriotic War of 1941-1945. There are also plaques related to communist ideology, busts of Soviet leaders, plaques commemorating local labour leaders and other monuments from the times of the USSR.

Each encounter with a new place begins with observing the simple need to find characteristic spots, points of reference, objects that in the first days will help us find our bearings in an unknown area. It is therefore important to find a way to organize the space as soon as possible, so one can navigate with confidence. It is

4 To take it briefly, oboo is a sacred, ritual place and, at the same time, a community rite that confirms and sanctifies the existence of a group. Oboo connects a group to a specific territory. Ritual practices related to a specific territory inherited from generation to generation create not only a sense of connection with landscape but also with ancestors. Thus, it can be said that both this sacred place and spatially defined practice that reproduces group memory are understood as a source of vital force associated with individual and collective identity. 
helpful to move from one point to another, and then freely improvise looking for new places, interesting walking routes or with shortcuts that will facilitate moving quickly if necessary.

In Kizhinga, it does not seem too complicated. It is a small town, crisscrossed by perpendicular and parallel streets. In its centre, as in most Russian regional towns, there is an administration building, a general store (univermag), a community centre and several smaller service points. One of the main landmarks is the Vladimir Lenin bust (previously it was a full-size statue) in front of the regional administration building. Although such monuments of the leader of the fallen state have lost their direct connotations with the Soviet ideology and system, they are still the carriers of the idea of the state structures. The stone Lenin standing here is literally the focal point not only of the town but of the entire region, a symbolic axis of the local spatial order. However, according to locals, even before 1991, this centrally placed symbolic object was not unambiguously associated with the symbolic centre of local space.

In late autumn 2012, the day after my arrival in Kizhinga, I was taken for a short tour around the area. The family who hosted me had a ready plan of what should be shown first. I did not try to interfere with their intentions even slightly. First, it would not be very polite. After all, they devoted their time, welcomed me at home, wanted to present me something, perhaps also receive something in return, and to show what was probably important from their point of view. Of course, I was curious to see what my hosts consider worth presenting to someone from the outside in the first place, something that in their opinion properly represents not only the world they live in, but also themselves.

On the way, we visited a small grocery store "Ulzy". From the outside, it did not stand out as anything special. In the centre of the room, against a massive refrigerator filled with frozen food and chunks of meat, stood a small bookcase. A sack of rice rested against its side. Yellow and blue khadaks ${ }^{5}$ were neatly stacked on the shelves, next to milk cartons, foil bags with chocolate candies, and right behind them paper packages with incense. A little higher was a row of postcards depicting the largest suburgaan of Kizhinga "Dzharun Khashor", temples of the local Datsan and picturesque landscapes of the valley. Miniature tankhas were hanging from the top shelf, on several centimetres long pieces of red yarn. The kind you often see under the windshield mirrors of cars, minibuses and trucks. As it soon turned out, one of the shop owner's cousins is a lama. The devotional items and ritual accessories available in the store had the appropriate blessing of the local Datsan. From time to time, the shop repaid with a donation for the needs of the monastery. Less than half an hour later we climbed to the top of the sacred Chelsana Mountain.

5 Buddhist ceremonial scarf (Mong. khadag, Tib. kadak). A symbolic gift, representing purity, compassion, good and friendly intentions. 
In traditional Mongolian cultures, the mountain (khada uula) was one of the basic, universal, multi-functional and ambiguous symbolic natural objects. As in many other cultural contexts, it can be described as axis mundi, the centre of social and symbolic order, the vertical centre of the universe, and at the same time the place of origin and creation. In the symbolic representations of the Mongolian peoples, mountain peaks were a transition point between the heavenly world and the human world. The heavenly world was identified, in short, with the habitat of the ancestors.

In the broadly understood Buryat culture, which is a part of the Mongolian cultural areal, the holy mountain played a particularly important role in defining and constructing the boundaries of collective, tribal-ancestral identity. It was often equated with the place of the origin, the birth of the group. It has also been defined as the place where human soul/consciousness comes from and returns while being part of the collective consciousness of this group. The holy mountain was treated as a place of accumulation and storage of the sülde (vitality, vital substance) that it grants to people. By definition, the sülde belongs to a specific group residing near the sacred natural object. ${ }^{6}$ This way of understanding the function of the mountain as the place of distribution of collective power and group consciousness would not change with the advent of Buddhism.

The Buddhist idea of incarnation will to some extent merge with the pre-Buddhist ideas of accumulating and materializing the life energy of ancestors in the next generations. ${ }^{7}$ In this way, the ancestors will return in the bodies of their descendants. Thus, the lineage or even the entire tribal-lineage can be viewed as collective entities functioning outside of linear time. Thus, a group understood in this way would be an accumulation of the collective vital force materializing in individual (Nanzatov, Nikolaeva, Sodnompilowa, Shaglanova 2008: 58).

In traditional Mongolian cultures, the mountain is therefore considered a place of experiencing the relationship of life and death, the movement of the cycle of successive generations, the duration of the group in time, but also outside time. The sacred natural site is an area of almost direct communication not only with ancestors, but also with those who will come in the next generations, that is, with those members of the group to whom the vital force will be passed on. However, this relation is not, as has already been said, simple and completely linear. The past, present and future are available here as a definite resource of the group's vital force. When things go wrong with a group or individuals, it is often interpreted as a depletion of the vital resources of a holy place. In this sense, it occupies the central position not only because of its location in the life space of the group, but also as a source of vital force, success, prosperity and even group's size.

${ }^{6}$ For example, childless married couples turned to the ancestral and tribal power of the holy mountain asking for "granting" a child.

7 Read more about the interpenetration of Buddhist ideas with pre-Buddhist beliefs in contemporary Buryatia in Galdanova 1997. 
A special, semantic dimension of the symbolism of the mountain was the antropomorphisation of names describing fragments of its space. They were identified with specific parts of the human body. For example, the top is the head of the mountain (khadyn tolgoi); ridge is denoted as the back of the mountain (khadyn niurgan); the southern slope of the mountain is the chest (über), the eastern and western slopes are the cheeks of the mountain (züün, baruun khasar), the remaining parts of the mountain are the ribs (khabirga), and the foot of the mountain is the lap of dress (khadyn khormoi). The personified mountain usually had a male identity. This can be seen, for example, in its connotations with the content of mythical epics, in which one of the central roles was played by a male hero ${ }^{8}$ (Nanzatov, Nikolaeva, Sodnompilowa, Shaglanova 2008: 52-57).

The status and function of the mountain and other holy places as a sacred centre corresponds to the figure personifying it, which can be called the "master/ ruler/host of the place". Just as a mountain structures the spatial order, the leader also structures the social order. Not only mountains, but also other significant and important natural objects were equated with the "master/ruler/host of the place" patronizing this or that territory. An example would be a drinking water source (bulag). Pure, life-giving water, of course, has connotations with the vital force of a group that can accumulate in an individual. The healing springs of mineral waters (arshaan) were referred to in a similar way. The miraculous, sacred healing power evoked associations with eternity (münkhe). Water could therefore be a source of immortality, understood, among others, as the continuation of group's existence.

The idea of the master/host of the place was usually expressed by one personified figure, but in fact it was a collective symbol, personifying the family and even the entire tribe. In various variants and stages of the socio-cultural process, the guardian spirits could be totemic animals, ambivalent spirits of the dead, spirits of ancestors, shamans, military chiefs and tribal leaders. In any case, these types of figures had the features of an ancestor assigned to a specific community, clan, family or a particular individual associated with a specific territory (Nanzatov, Nikolaeva, Sodnompilowa, Shaglanova 2008: 60-65, 180-183).

The image of the territory, the living space of people, of course, shows a multitude of specific points, marking natural and cultural landmarks, signs of the presence and existence of human groups. Sacred locations not only construct the perception of space by defining the boundaries separating the domesticated

8 In traditional Mongolian cosmogonic myths, two sacred, complementary figures of demiurges usually appear. They are: the mother goddess and the male demonic hero. Mountains are considered to be the product of the male demiurge and therefore are identified with the male element. On the other hand, the valleys and lowlands were created by the mother goddess, so they usually belong to the symbolic female order. Although the symbolism of the mountain has primarily male connotations, they are not always unambiguous - the ambivalence is caused, for example, by the above-mentioned parental functions of the mountain. 
from the untamed world. They also create its internal structure along with symbolism and an internal hierarchy of values. Researchers distinguish three basic contexts in which the organization and symbolism of space in the culture and tradition of Mongolian peoples should be considered and analysed: economic, political and ecological (Nanzatov, Nikolaeva, Sodnompilowa, Shaglanova 2008: 197-200).

From the economic point of view, the territory is primarily a place for grazing herds of cattle, horses and sheep. The land itself did not have the value it had in agricultural cultures. This does not mean that nomads did not become attached to specific territories, specific seasonal pastures, or routes of passage. The stereotypical territoriality ascribed to them was practically absent even in the cases of nomads moving in open desert-steppe spaces. In the case of most semi-settled Buryat groups, occupying the valleys on the border of the Central Asian steppe and Siberian boreal forests, spatial location and attachment to specific territories were even more pronounced.

The symbolism of space and its internal hierarchy have obvious political connotations. In Buryat folklore, these connotations are expressed, among others, in the relations between the dominant mountain in the landscape and the institutions of power, hierarchy and social organization. In the symbolism of the mountain as the spatial centre of the tamed world, we also see the relationship of the group leader with the centre of the territory belonging to the group. For example, Buural baabai (from bur. Grey Father), the ruler/host of the Chelsana Mountain, which is a spatial dominant of the Kizhinga Valley and a symbol of the collective spirit of ancestors; it is sometimes also called Otog noyon, or literally the "clan leader". (The word noyon means "head", "leader", and the word otog means "clan").

Social and political issues are related to the ecological context. The above-described oboo cult is not only a cult of nature, mountains, landscape deities, etc. It is a cult form of describing the relationship of a group with the natural environment they dwell in. The belief that the collective spirit of ancestors incarnates in natural objects, becoming the "ruler/host of the place", lies at the basis of social and natural symbolism, in which social meanings and connotations will dominate over strictly natural ones (Nanzatov, Nikolaeva, Sodnompilowa, Shaglanova 2008: 219).

Semi-nomadic Buryats cultivate close relationship with their ancestral territory, because they believe that it concentrates their vital force and the source of their collective and individual identity. The ancestors should be worshiped regularly in sacred natural places identified with their energy. The energy of the ancestors and natural places was perceived at the same time as the current vital energy of the entire group and its individuals. Important events in the lives of groups and individuals therefore required resorting to their ancestors in order to receive the vitality, luck and happiness they embodied. This could take place on the occasion of cyclical, annual rituals to ensure the prosperity of the group, good breeding of 
herds, fertility of pastures, etc. But the resource was also used occasionally. For example, the ancestors were asked for success in marriage, treatment of diseases, the need to travel - which is especially important in the case of nomadic and semi-settled communities. Moreover, it was believed that those who live far from their native lands should appear at least once a year in a holy place and renew their relationship with their ancestors and their own life force. Usually, gifts were made to ancestors, in the pre-Buddhist period they were most often animal sacrifices.

When in the $18^{\text {th }}$ century Buddhism spread in the Kizhinga Valley, the local population for many generations led a semi-settled lifestyle. The new religion further cements group ties to the territory. The first stationary Buddhist monastery, erected in the middle of the 18th century by the local Khori-Buryats, would become another important object linking people with the territory they inhabit and use. At the same time, the community of the Kizhinga Valley would release the first generation of local lamas, who would gradually take over ritual and sacred functions so far performed by clan shamans. In time, Buddhist suburgaans would appear on the sacred Chelsana Mountain, and the surrounding holy places associated with it would absorb Buddhist symbolism and Buddhist forms of worship.

This does not imply, however, that pre-Buddhist ideas and the forms of their expressing will disappear. Natural sacred places that serve as oboos will not cease to be arenas of traditional Buryat annual rites: the beginning of the year, sacrificial cults dedicated to heaven, guaranteeing the fertility and growth of the herd, ancestor worship and other rituals that confirm the social order and the rules governing the social world along with hierarchies, social roles, and intragroup relations (Skrynnikova 2005).

We had been standing at the top of Chelsana for a long time. From above, you could see the roofs of Kizhinga town less than a few kilometres away and the vast expanse of a steppe valley. Finally, my hosts started the ritual serzhem: ${ }^{9}$ they poured milk from the carton high into the sky, sprinkled the rice, incensed and blessed in the local datsan (as the owner of the "Ulzy" shop assured us). They had not been here for a long time. And yet Chelsana was worth visiting at least a few times a year. Especially on the occasion of prayers organized by local lamas. Or at least once a year during the Eryn gurban naadan (Three games of real man), a folk summer festival. It holds traditional sports - wrestling, archery and horse racing. At the foot of Chelsana there is a special square with a small wooden tribune. Right next to it, there is a stage where during the fests one could watch dance

9 Literally "golden drink". A traditional rite to offer a liquid substance, most often milk or alcohol, to the deities or guardian spirits of a place. The serzhem is an element of the Buddhist ritual system. Its roots, however, go back to pre-Buddhist beliefs and are associated with the traditional cult of ancestors and nature. 
shows, competitions, recitations and, above all, performances by local bands performing traditional music or more often folklore stylized pop music. ${ }^{10}$

Similar holidays were also held in the Soviet period. After 1956, local party committees adapted the traditional Naadans to the new needs. Surkharbaan, a secular folk festival, during which people were entertained, participated in "three games of real man". It was supposed to be a folkloristic phenomenon of a new type. Tradition had to be stripped of its sacred roots, reduced to the role of festive entertainment and recreation. Surkharbaans were also held during the summer, when nature was at its peak. Kolkhoz collective folk festivities were organized in connection with the commencement or completion of breeding and agricultural works, haymaking, etc.

The strictly sacred dimension has moved into the area of unofficial, hidden practices. It is difficult to clearly define them as individual practices. They have always had a specific collective dimension. Secret trips to holy places were associated with the ideas of collective identity and vitality associated with the place of guardian spirits, "rulers/hosts of the place", etc., as well as with the unofficial, hidden activity of educated emchi-lamas (doctors of Tibetan medicine) who managed to survive the repression.

Thus, during the Soviet period, Chelsana was visited in secret, mainly for family or private matters, usually at important moments in life. An important motive for visiting holy places was the uncertainty caused with changes in life. It could be, for example, getting married, but also a change of place of residence related to moving to the city for study or school, completing military service or assigning work in another region of the USSR. The interlocutors, when asked about their motivation, generally indicated success in the implementation of life plans, their own and family happiness, fulfilment of plans, health, success and wealth, etc.

In the narratives of the senior inhabitants of Kizhinga, born no later than in 1956 , there is a rather interesting story allegedly passed on by local veterans, the so-called Great Patriotic War 1941-1945. (During my research visits in Kizhinga, I heard it in several variants from various interlocutors). A local veteran supposedly took an amulet to the front, which was to protect him from danger. In the story of the two interviewees, it was simply a bag with "soil of Kizhinga". In turn, three others claimed that it was specifically a bag of soil specifically from Chelsana, and in another interviewee's story it was supposed to be soil taken from a holy place in the vicinity of Kuorka, a village located in the southern part of the Kizhinga region.

During the artillery fire, the holder of the amulet temporarily entrenched himself together with a Russian soldier. Suddenly a Light Rider appeared to him. In

10 The feast in various local variants is celebrated throughout the Turkish-Mongolian steppe. In Polish anthropological literature they were described, among others, by Ewa Nowicka (2016) and Łukasz Smyrski (2010). 
most versions it was the ruler/host of Chelsana, and according to one interviewee it was supposed to be Sagaan Übgen (White Old Man). ${ }^{11}$ The Light Rider shouted at him to run away or he would die. The Russian was also supposed to see the rider, but he could not understand what he was saying. Meanwhile, Buryat, jumping out of the trench, grabbed him by the sleeve and pulled him outside. Moments later a bullet hit the trench. Until the end of the war, the Russian was said to follow his comrade-in-arms, convinced that he was protected by the powerful Guardian Angel (angel khranitel').

This story can be examined on many levels. Interesting is the topic of Buryat and Russian fellowship, in which the Buryats represent themselves as possessing wisdom and protection of the spirits of their ancestors. The Russians and the Buryats form one integrated group in this story, although it is internally diversified and hierarchically valued. The Russians are generally the dominant party, but in this story, the Buryats have more resources to ensure survival. The interconnection of pre-Buddhist, Buddhist and Christian forms and concepts is also interesting here. Due to the subject of the article, I am merely pointing to this thread, but a more detailed analysis of this and similar stories could undoubtedly reveal many interesting clues on how the Buryats understand their place in the multi-ethnic Russian state-national community.

One day, while sitting in the library of the district house of culture in Kizhinga and reading folders with the annals of the local newspaper "Dolina Kizhingi", I came across an article describing this story. ${ }^{12}$ To this day, I am not able to finally conclude whether the article was based on several different stories that were remembered as one story. Or the other way around - someone's memories grew into the universal experience of many local veterans. Finally, my interlocutors could repeat the story heard from a real veteran/veterans or read from the newspaper article, which they considered credible, and moreover, concerning the experience of more than one person.

From our point of view, the most important thing is that this story revives a figure identified with the native territory and the collective belonging to it, and especially with the power of ancestors understood as a social resource in life. Above all, however, the aforementioned story connects the local world in an interesting way with the myth of the great patriotic war. Thus, it is one of many instances that give an idea of how local symbols, myths and folklore intertwine with official, state ideological paradigms, introducing them into the ambivalent circuits of various local traditions.

11 "White Old Man" is, in short, a figure involved in the Buddhist cult, but rooted in the pre-Buddhist worship of nature, longevity and fertility. The cult of the "White Old Man" is related to the influence of Chinese culture on the broadly understood culture of the Mongolian steppe. In Buryat culture, the "White Old Man" also has connotations with the pre-Buddhist cult of fire.

12 Without author, 2006, Chelsana - eto sviatynia, “Dolina Kizhingi”, no. 45-46, pp. 8-9. 
The return of traditional symbolism to the official image of space took place in the early 90s. In the area of the Kizhinga Valley this process is particularly evident in the example of the re-implementation of objects belonging to the Buddhist tradition into the official cultural landscape. In 1992, a series of articles appeared in the local press calling for the need to raise funds and rebuild the suburgaan "Dzharun Khashor" 13 destroyed by the communists. It is worth mentioning here that an important stimulus for the revival of Buddhism, not only in the Kizhinga Valley, but throughout Buryatia, was the visit of the $14^{\text {th }}$ Dalai Lama in 1991. During his stay in Buryatia, the leader of the Gelug Buddhist school blessed, among others, the plans to reconstruct of the suburgaan in Kizhinga.

In the same year, during the $10^{\text {th }}$ session of the District Council committee, the chairman of the newly formed Kizhinga Buddhist Association, Dashi Bayartuyev, gave a speech on the role of Buddhism in the history and social life of Buryatia, the need to restore religious institutions as important elements of social order and the importance of Buddhism for local culture and tradition. He also mentioned of purges, but quite vaguely and carefully. He frequently put the emphasis of his speech on the future. Therefore, Bayartuyev recalled the upcoming $250^{\text {th }}$ anniversary of the Kizhinga Datsan and the need to properly prepare for the celebration. Of course, the first thing to do was to rebuild the monastery, which was destroyed in the 1930s. A year earlier, the cornerstone for the reconstruction was laid by the Bakula Rinpoche, Buddhist hierarch from Ladakh, visited Kizhinga.

In fact, Bayartuyev's speech can be described as icebreaking on a local scale. Despite the full acceptance of recent local activists of the Communist Party of the Soviet Union, the enthusiasm of the believers and the support of old local lamas who managed to survive the purges, the religious revival was not without difficulty. The problem turned out to be, among others, in lack of competence and under-education of the new generation of lamas. After several decades of planned eradication of religious practices, the believers also did not quite know how to behave in holy places.

One of my interlocutors recalls that period as follows:

In the early 1990s, there were such quickly trained lamas who confused and twisted everything. They used to perform [rituals - AJ] the way they wish introducing their own orders. I remember it was a total disaster. One of such lamas appeared in Kizhinga and said that bottles cannot be taken from Chelsana, [...] he said something like this: 'the deity thinks it is his bottle, and you are taking it, you are not allowed to do so'. As a result, there were unbelievable heaps of empty bottles. Nobody dared to take them due to the words of the lama. Who came up with such nonsense? [...] Then some wise man said that when these empty bottles lie there, insects enter and then die. People striving to perform good deeds, cause death of living beings and spoil

13 "Dzharun Khashor" is one of the largest stupas in Russia. It was erected around 1914 with the financial effort of the local Khori-Buryats in the vicinity of the present-day village of Ushkhaita five kilometres west of Kizhinga. Its form was modelled on the Bodanath stupa standing in the centre of the Nepalese capital, Kathmandu. The suburgaan was blown up in the second half of the 1930s. The reconstruction was completed in 2000. 
their karma. So people started breaking these bottles. Then it got so messy, it is hard to believe. A pile of broken glass. Finally, in 2001, we made an ecological expedition there and transported a whole truck of glass from there. Then, fortunately, the local shireete-lama [abbot - AJ] started explaining to people not to listen to nonsense and to treat the holy place with respect. And finally, they clean up after themselves. [O: 8-9]

Twenty years after the described events, the slopes of Chelsana were not filled with rubbish and broken bottles. We walked down a solidly trodden path behind our backs, leaving a sacred peak on which stood a Buddhist suburgaan, an altar built into a rocky cliff, several rows of wooden benches, a small shed for lamas, and a lonely tree, almost entirely hung with khadaks and votive flags with the image of an "air horse" (khii morin). At the foot of the mountain, where we found themselves after a dozen or so minutes, male energy, according to the tradition, should give way to female energy.

In the past, valleys were identified with a bowl filled with life-giving juices, a bowl that fed people and their herds. Even at the beginning of the last century, people did not settle here in densely built-up villages. The valleys were divided into large parts, scattered over tens of kilometres, used by individual families creating larger territorial and family relationships. In 1941, a new town was established in the Buryat locality called Shuluuta. Therefore, Kizhinga does not stand out when compared to thousands of other local towns scattered over the vast area of the former USSR. And like many modern "urban-type villages" (selo gorodskogo tipa), it is a typical product of Soviet collectivization. The seat of local party authorities was built in its centre. Today, the old brick building hosts the local community centre and district library. The modern concrete building of the district administration was erected much later.

In front of the entrance to the new headquarters of the administration, an awkward bust of Vladimir Lenin was placed on a high pedestal, which closes the upper part of the main street of Kizhinga. A few hundred metres further down the street, there is another monument. It represents Darma Zhanaev, the local hero of the Great Patriotic War. A Buryat soldier died in April 1945, fighting in the ranks of the Red Army in the Battle of Berlin. The statue of the local hero is surrounded by a regularly painted fence, and a small square in front of the pedestal. It remains in good condition throughout the year.

Every year, on May 9, in Moscow on Red Square, the central government celebrates the Victory Parade, broadcasting across the country. On this day, Kizhinga also has a festive atmosphere. Solemn ceremonies in honour of the great victory are held here, as well as occasional parties and merry festivities. Anniversary wreaths are placed in front of the bust of the Kizhinga hero, next to them, students from local schools are on guard, regional officials speak, and the hymns of the Russian Federation and the Russian Federal Republic of Buryatia are sung. The loudspeakers carry war songs from the iron repertoire of the Alexander Choir across the village. 
On Zhanaev's cast-iron chest, one could see the shapes of medals awarded for bravery in the struggle for the Soviet homeland, which appeared only two decades prior to his heroic death. The monument of the demiurge and the first leader of the state, in the name of whom a local soldier died, is on guard in front of the district administration building. Less than a century has passed since the symbolic centre of the local world was redefined around this building and the new spatial, ideological order was structured, destroying brutally the old sources of social authority, their ideological foundations. The symbolic centre of space, previously referred to as a sacred peak, khadyn tolgoi, the head of a mountain, identified with the image of the collective ancestor and founder of territorial/ancestral group, found a new location and form.

Persistent wading into effective analogies between the figures of the Khan, the taishaa, the head of the family or the noyon, and the founder of the Soviet state may lead us astray sooner or later. Nevertheless, it would not be the first symbolic and ideological substitution of forms or concepts that one could observe and describe by examining the rich repertoire of Soviet symbolism embodied in propagandist spatial forms as well as in traditional, proven narrative structures. ${ }^{14}$ (At this point, it is worth mentioning the anecdotal connotations of the world's largest monument depicting the head of Vladimir Lenin in the centre of Ulan-Ude with traditional Buryat culture. In this context, let us just recall that the Russian word golova merges with the word gulbaa used by the Buryats, meaning leader, senior, chief.)

In conclusion, let's go back to the questions that opened this article. First, how does local tradition and culture interact with the state ideology, and second, how is it possible that symbols whose meaning and connotations seem to be difficult to reconcile, or even opposing to each other, can create a coherent image of the local world? Trying to answer these questions, let us once again recall the concept of cultural landscape. In this case, it should be seen as a palimpsest - a model of a territorial, cultural system that encompasses a variety of co-occurring cultural contexts (understood as sign systems) of the same place (cf. Breslavsky 2012: 9-15). Each of these contexts creates layers of meaning of one landscape. Of course, these layers are not separate from each other. Not only they themselves as a whole, but also their individual elements can interpenetrate, enter into relationships, dialogue and even create new codes. They are also characterized by the possibility of revealing the hierarchy of elements of interpenetrating contexts and their ambiguity.

The description and analysis of the meanings of the cultural landscape of the Kizhinga Valley could also be carried out using the concept of mythologems. In this way, we would recreate the semantic contexts of its layers. So, in short, we

14 More on the subject of the presence of symbolic religious forms and ritual structures in communist propaganda, one can find, among others, in the book by Marcin Kula Religious Communism (2003). 
have a story about the USSR, understood today as a difficult, but also glorious stage in the history of the Russian state/empire. Within it, the mythologem of Lenin functions, of a great demiurge who, more than the leader of a brutal revolution, is today perceived as the creator of a single, cohesive state and "Russian people" (the 5th article of the RF constitution describes Russian citizens as a "multinational people" - mnogonatsionalny narod). Russification of the Soviet type, together with the far-reaching unification of collective consciousness, identity, language, lifestyle, etc. created contemporary supra-regional, trans-ethnic, state community of Russian citizens (Rossiyanie). The mythologems of the great Patriotic war, especially those derived from local symbolic resources, create a sense of shared fate, experiences, common sacrifice, heroism and superhuman effort. In the cultural landscape of the Kizhinga Valley, we can also find mythologems rooting the local culture in the broadly understood traditional Asian civilization contexts: Buddhist, Indo-Tibetan, that of the Great Steppe, etc. These redefined elements taken out of contexts create a coherent processual reality of the sociocultural territory of our interest.

"The ideologization of space may take place consciously, according to previously selected criteria (e.g. the goals one wants to achieve are taken into account) or unconsciously, e.g. as a passive record of history. In the second case, it is modified spontaneously, along with the entire human environment: by adjusting to the existing historical circumstances, one automatically subordinates the environment. In this way, space can automatically encode ideological systems within itself" (Jędrzejczyk 2004: 240). The dominant features of this "record of history" will usually be the discourses of power or the traces left by the more or less officially recognized, maintained or destroyed, reconstructed or forgotten tradition. ${ }^{15}$

After the collapse of the USSR, the long process of producing material symbols of the Buryat "national space" began. Certainly, it should be referred to in the context of the wider phenomenon of national revival in the territory of the former USSR. ${ }^{16}$ The phenomena that co-create it were usually interpreted as ideological processes created by the national elite aimed at mobilizing the group by identity. ${ }^{17}$

15 This conclusion is essentially based on the debatable Foucauldian claim that history is in fact a discourse of power (cf. Foucault 1998: 74).

${ }_{16}$ The problem of the so-called national revival in Siberia was a popular subject of research at the turn of the $21^{\text {st }}$ century. It has a rich literature in Russian and English. In the area of Polish ethnology and sociology, the problem was also widely described (Nowicka, Wyszyński 1996; Nowicka 2000; Smyrski 2010; Wyszyński 2010).

17 In the case of the Siberian autonomous republics, unlike, for example, the newly established states of Central Asia, the practices of cultural self-determination were not followed by similar political process. The Buryat ethno-social elites did not make any serious attempts to bring about the political self-determination of the Buryat nation (they had neither such opportunities nor aspirations), remaining in the area of practices aimed at strengthening collective ethno-cultural identification, producing a regional identity within the Russian state and nation, and reviving religion, folklore, etc. (cf. Amogolonova 2008; Skrynnikova 2008). 
However, if we look at this process from the local level, we can see that it was quite spontaneous and not always planned (not to say chaotic) actions. This is also visible at the level of local cultural landscapes.

Local and regional ethnic and national symbolism currently refers to differences in customs, religion and elements of tradition. On the strictly political level, however, it is essentially the same as the official ideology and the meaning of state symbols. The policy is supported by the state, which, in turn, is not interested in far-reaching separateness between the regions and the ethnic/national groups that compose them. In the political dimension, Buryatness is therefore one of the invariants of the state universe of the symbolic and ideological trans-ethnic Russian nation understood as a "multinational people" (to recall the content of article 5 of the RF constitution). Thus, the production of Buryat ethnic myths does not go beyond the limits of the state myth. They do not have to be identical to it. The most important thing is not to stand in open opposition to it. ${ }^{18}$

On the central street of Kizhinga, we will find the bust of Darma Zhanaev, the local soldier in a state Soviet/Russian military uniform, but we will not see Lubsan Samdan Tsydenov, a local charismatic religious and political leader who, about a hundred years ago, cut himself off from a Russia mired in civil war to head the local Buddhist quasi republic. Death at the front of the cruel war, thousands of kilometres away from home, will be proudly called the fulfilment of duty to the motherland. But the attempts to create one's own state structures, even if accidental, based on the local tradition formed as a result of specific, locally formed cultural and civilization influences, will remain a local curiosity, a social utopia, born somewhere in the ideological antipodes of civilization and political centres. Stupas dedicated to local religious and social leaders are hidden deep in the forest, and the memory of the shortly-lasting state, established once in the valleys of the Kodun and Kizinga rivers, are still not widely known and legible in other regions of Buryatia. However, being far from the interest of outsiders, they become an important, intimate symbolic resource of the local community.

\section{Bibliography}

Amogolonova D.D.

2008 Sowriemiennaja burjatskaja etnosfera: diskursy, paradigmy, sociokulturnyie praktyki, Ułan-Ude.

Amogolonova D.D., Batomunkuev S.D., Varnavskiy P.K., Kuklina V.V., Misyurkeeva Y.S., Sodnompilova M.M.

2008 Burjaty: sociokulturnyje praktyki pieriehodnogo pierioda, Irkuck.

${ }_{18}$ For the topic of the open tension between traditional cultural/ethnic symbols and the externally imposed Soviet spatial "implants" in neighbouring Mongolia see Michalev 2009. 
Breslavskiy A.S.

2012, Postsowietskij Ulan-Ude. Kulturnoje prostranstwo i obrazy goroda(1991-2011 gg.), Ulan-Ude

Cyrempiłow N.W.

2013 BuddizmiImpierija.Buriatskajabuddijskajaobszczinaw Rossii(XVIII-nacz.XXw.), Ułan-Ude.

Foucault M.

1998 Wykład z 28 stycznia 1976, trans. M. Kowalska in: M. Foucault (ed.), Trzeba bronić społeczeństwa. Wykłady z College de France, 1976, Warszawa, pp. 73-102.

Galdanova G.R.

1997 Tradicjonnyje wierowanija burjat w systemie buddizma in: G.R. Galdanova (ed.), Buriackij buddizm: istorija i ideologia, Ułan-Ude.

Jędrzejczyk D.

2004 Geografia humanistyczna miasta, Warszawa.

Kopaliński W.

1975 Słownik wyrazów obcych, Warszawa.

Kula M.

2003 Komunizm religiopodobny, Kraków.

Michalev A.B.

2009 Sowietskije memoriały v Mongolii: kollektiwnaja pamiat' i borba za simwoliczeskoje prostranstwo, "Diaspory", vol. 2, pp. 198-220.

Nanzatov B.Z., Nikolaeva D.A., Sodnompilowa M.M., Shaglanova O.A.

2008 Prostranstwo $v$ traditsionnoj kulturie i praktykach mongolskich narodow, Moskwa.

Nowicka E. (ed.)

2000 Wielka Syberia małych narodów, Kraków.

Nowicka E., Wyszyński R.

1996 Lamowie i sekretarze. Poziomy więzi społecznej we współczesnej Buriacji, Warszawa.

Nowicka E.

2016, Korzenie ałtargany sięgaja głęboko Buriaci między Rosją, Mongolia i Chinami, Kraków.

Sablin I.

2016 Governing Post - Imperial Siberia and Mongolia, 1911-1924, Socialism and Nationalism in the State and Autonomy Building, London.

Skrynnikova T.D.

2005 Dwie Mongolii: osobiennosti sriedniekwiekowyh identifikacjonnyh praktik, "Wiestnik Jewrazjii", vol. 2, pp. 208-232.

Smyrski Ł.

2010 Ajdyn znaczy księżyc. Narody południowej Syberii, Warszawa.

Without author

2006, Chelsana - eto sviatynia, "Dolina Kizhingi”, no. 45-46, pp. 8-9.

Wyszyński R.

2010 Narodziny czy śmierć narodu. Narodowotwórcze działania elit białoruskich i buriackich po upadku ZSRR, Warszawa. 